\title{
Hypophagic effects of propionic acid are not attenuated during a 3-day infusion in the early postpartum period in Holstein cows ${ }^{1}$
}

\author{
S. E. Stocks and M. S. Allen ${ }^{2}$ \\ Department of Animal Science, Michigan State University, East Lansing 48824-1225
}

\begin{abstract}
We previously showed that propionic acid was more hypophagic than acetic acid when infused intraruminally in cows in the postpartum period and that the degree of hypophagia from short-term propionic acid infusion $(18 \mathrm{~h})$ was related to the acetyl coenzyme A $(\mathrm{CoA})$ concentration in the liver. The objective of this experiment was to evaluate adaptation over time with longer-term infusions over $3 \mathrm{~d}$. Twelve multiparous cows (2-13 d postpartum) were blocked by calving date and assigned randomly to treatment sequence in a crossover design experiment. The experiment was $12 \mathrm{~d}$ long with covariate periods preceding each 3 -d infusion period. Treatments were $1.0 \mathrm{M}$ propionic acid or $1.0 \mathrm{M}$ acetic acid, infused intraruminally at $0.5 \mathrm{~mol}$ of volatile fatty acids/h beginning $6 \mathrm{~h}$ before feeding and continuing for $78 \mathrm{~h}$ with $3 \mathrm{~d}$ between infusions. Propionic acid decreased dry matter intake (DMI) relative to acetic acid (15.9 vs. $17.0 \mathrm{~kg} / \mathrm{d})$. However, a period-by- treatment interaction was detected for DMI. During period 1 , propionic acid decreased DMI relative to acetic acid (14.3 vs. $17.5 \mathrm{~kg} / \mathrm{d}$ ) because of a reduction in meal size $(1.30$ vs. $1.65 \mathrm{~kg})$, with no effect on intermeal interval. Propionic acid decreased DMI over the first $4 \mathrm{~h}$ following feeding ( 5.86 vs. $8.23 \mathrm{~kg}$ ) but did not affect DMI 4 to $24 \mathrm{~h}$ after feeding. The depression in DMI in period 1 was positively related to hepatic acetyl-CoA concentration during the covariate period. Propionic acid was increasingly more hypophagic than acetic acid as hepatic acetyl-CoA concentration was elevated. No treatment-by-day interaction for DMI was observed, suggesting little or no measurable adaptation to treatment over the 3-d infusion period. These results suggest that hypophagia from propionic acid is enhanced when
\end{abstract}

\footnotetext{
Received February 1, 2013.

Accepted April 3, 2013.

${ }^{1}$ This project was supported by National Research Initiative Competitive Grant no. 2008-35206-18854 from the US Department of Agriculture (USDA) National Institute of Food and Agriculture (M. S. Allen) and by USDA National Needs Graduate Fellowship program, grant number 2007-38420-17753 (S. E. Stocks).

${ }^{2}$ Corresponding author: allenm@msu.edu
}

hepatic acetyl-CoA concentrations are elevated, such as when cows are in a lipolytic state.

Key words: propionic acid, feeding behavior, lipolytic state

\section{INTRODUCTION}

In the weeks following parturition, cows are in negative energy balance as a result of increased energy demand at the onset of lactation and suppressed feed intake in the peripartum period (Ingvartsen and Andersen, 2000; Gulay et al., 2004). Whole-body glucose demand more than doubles following calving (Bell, 1995) and propionate accounts for up to $60 \%$ of hepatic glucose release during this time (Reynolds et al., 2003). To support milk production and improve energy balance after parturition, starch sources are included in diets to increase energy and provide glucose precursors (Allen et al., 2009). Ruminal starch fermentability varies from 50 to $94 \%$, depending on processing method and grain type (Huntington, 1997), but limited research exists examining the effects of feeding a highly fermentable starch source after calving. Dann et al. (1999) reported that steam-flaked corn (a more ruminally fermentable starch source) tended to decrease DMI compared with cracked corn when fed to cows in the postpartum period. Greater ruminal fermentability of starch increases propionic acid production in the rumen (Oba and Allen, 2003a) and the flux of propionic acid to the liver increases rapidly following feeding (Benson et al., 2002).

Intraruminal propionic acid infusion has been shown to be hypophagic in ruminants and this effect is greater for cows early lactation compared with mid lactation (Oba and Allen, 2003b). Recent work in our laboratory has shown that hypophagic effects of propionic acid infusions are more pronounced when cows are in a lipolytic state (Stocks and Allen, 2012). Elevated plasma NEFA concentration during lipolysis increases the concentration of hepatic acetyl-CoA, which can be oxidized in the tricarboxylic acid cycle or exported as ketones. Intraruminal infusion of propionic acid reduces plasma BHBA concentration without reducing plasma NEFA concentration (Stocks and Allen, 2012), suggesting increased oxidation of liver acetyl-CoA, rather 
than a reduction in lipolysis leading to the reduction in plasma BHBA concentration. We proposed that propionic acid stimulates oxidation of hepatic acetyl-CoA in the tricarboxylic acid cycle, generating ATP and sending a satiety signal to brain feeding centers (Allen et al., 2009).

Despite consistent hypophagic effects of propionate during short-term infusions in our laboratory, the potential exists for adaptation over long-term infusions, which might affect feeding responses. Possible adaptations to propionic acid include altered concentrations of hormones or metabolites in plasma, or alterations in gene expression. Therefore, the objective of this experiment was to determine feeding response to longer-term (3 d) propionic acid infusion. We hypothesized that intraruminal infusion of propionic acid, compared with acetic acid, would decrease feed intake, but that the effects would be attenuated over time.

\section{MATERIALS AND METHODS}

\section{Animals, Housing, and Diets}

The Institutional Animal Care and Use Committee at Michigan State University (East Lansing) approved all experimental procedures for this experiment. Twelve multiparous, lactating Holstein cows were ruminally cannulated at least $45 \mathrm{~d}$ before calving and cows were housed in individual tie-stalls for the 12-d duration of the experiment. Cows were fed once daily (1200 h) at $115 \%$ of expected intake and received a common

Table 1. Ingredients and nutrient composition of the experimental diet

\begin{tabular}{lc}
\hline Item & Amount \\
\hline Diet ingredient, \% of dietary DM & \\
Corn silage & 43.0 \\
Alfalfa silage & 29.4 \\
Alfalfa hay & 6.4 \\
Ground corn & 10.0 \\
Soybean meal & 7.2 \\
Vitamin and mineral mix ${ }^{1}$ & 4.0 \\
Nutrient composition, \% of dietary DM & \\
DM, \% & 47.6 \\
OM & 93.0 \\
Starch & 19.1 \\
NDF & 38.6 \\
ADF & 28.8 \\
CP & 14.4 \\
Ether extract & 3.3 \\
\hline
\end{tabular}

${ }^{1}$ Vitamin and mineral mix contained $24.8 \%$ ground corn grain, $21.5 \%$ dehydrated cane molasses, $11.2 \%$ limestone, $9.6 \%$ blood meal, $9.0 \%$ sodium bicarbonate, $6.6 \%$ dicalcium phosphate, $4.2 \%$ ReaShure choline (Balchem Corp., New Hampton, NY), 3.1\% magnesium sulfate, 2.8\% salt, $2.0 \%$ animal fat, $1.5 \%$ niacin, $1.3 \%$ trace mineral mix, $0.95 \%$ biotin, $0.70 \%$ Yeast Plus (Chr. Hansen, Milwaukee, WI), $0.54 \%$ vitamin ADE premix, $0.32 \%$ selenium yeast, and $0.09 \%$ Rumensin 90 (Elanco Animal Health, Greenfield, IN). experimental diet from parturition through the end of the experiment. The experimental diet (Table 1) was composed of corn silage, alfalfa silage, alfalfa hay, ground corn, soybean meal, soy hulls, and a vitamin and mineral mix and formulated to meet requirements for absorbed protein, minerals, and vitamins (NRC, 2001).

\section{Experimental Design and Treatments}

The experiment was a crossover design with a covariate day each period preceding the $3-\mathrm{d}$ infusions to establish baseline measurements. Cows were between 2 and $13 \mathrm{~d}$ postpartum at the start of the experiment and were assigned to block by calving date, and then randomly assigned to treatment within a block. The experiment was $12 \mathrm{~d}$ long and conducted with 3 blocks of cows containing 4 cows each. Each covariate day (d 1 and 8), was $1 \mathrm{~d}$ before the start of infusions in each period. Following each covariate day was an 18-h rest period before the initiation of the infusion and there was a 3 -d rest period between periods. Treatments were infused on d 3 to 5 (period 1) and d 10 to 12 (period 2) of the experiment. Jugular catheters were inserted according to the procedure of Bradford et al. (2006) $2 \mathrm{~d}$ before the start of the experiment and were maintained through the end of the experiment. Treatments were propionic or acetic acids $(1 \mathrm{~mol} / \mathrm{L})$ infused continuously into the rumen at $0.5 \mathrm{~mol}$ of $\mathrm{VFA} / \mathrm{h}$ for $78 \mathrm{~h}(39 \mathrm{~mol} / 78$-h infusion). Solutions were infused at $500 \mathrm{~mL} / \mathrm{h}$ using peristaltic pumps (\#78016-30; ColeParmer Instrument Co., Vernon Hills, IL) with Tygon tubing (1.6-mm i.d.) from individual containers that were manually replenished hourly to ensure an accurate hourly infusion rate. Infusions began $6 \mathrm{~h}$ before feeding on the first day of each infusion period to approach a steady state VFA concentration in the rumen before starting feeding behavior monitoring.

Cows were blocked from feed from 1000 to $1200 \mathrm{~h}$ daily to weigh and collect orts and fresh feed was offered at $1200 \mathrm{~h}$. Samples of all diet ingredients $(0.5 \mathrm{~kg})$, the TMR $(0.5 \mathrm{~kg})$, and orts $(12.5 \%$ of the remaining feed) were collected daily and composited into 1 sample per cow per block for analysis. Body weight and BCS were recorded on d 1 of the experiment. Body condition was scored by 3 trained investigators using a 5 -point scale, where $1=$ thin and $5=$ fat, as described by Wildman et al. (1982). Cows were milked twice daily at 0500 and $1700 \mathrm{~h}$ in their stalls during covariate and infusion days and in the milking parlor on remaining days.

\section{Covariate Sample and Data Collection}

Feeding behavior was monitored for $24 \mathrm{~h}$ on each of the covariate days. Feeding behavior data (chewing, 
feed disappearance, and water intake) were recorded via computer every $5 \mathrm{~s}$, which allowed calculation of meal size, intermeal interval, water intake, and eating, ruminating, and total chewing time, as described by Dado and Allen (1993). Blood, rumen, and fecal samples were collected every $4 \mathrm{~h}$ for $24 \mathrm{~h}(\mathrm{n}=6)$ during each covariate day. Rumen fluid samples were collected from 5 different sites in the rumen, squeezed through a nylon screen, and $\mathrm{pH}$ was determined immediately. Samples were stored at $-20^{\circ} \mathrm{C}$ for later analysis of VFA and ammonia-N concentrations. Blood samples were collected via jugular catheter and transferred into 2 Vacutainer tubes (Becton Dickinson, Franklin Lakes, NJ): one with potassium EDTA and one with potassium oxalate and sodium fluoride (as a glycolytic inhibitor). Blood samples were cooled on ice until centrifugation at $2,000 \times g$ for $20 \mathrm{~min}$ (within $15 \mathrm{~min}$ of sample collection); plasma was collected and frozen at $-20^{\circ} \mathrm{C}$ for analysis of metabolites and hormones. A 1-mL aliquot of plasma from each potassium EDTA tube was stored with $0.05 M$ benzamidine (final concentration) to prevent enzymatic degradation of glucagon. Liver tissue was collected by needle biopsy (Bradford and Allen, 2005 ) once at the end of each covariate day and stored at $-80^{\circ} \mathrm{C}$ until analysis for acetyl-CoA concentration.

\section{Infusion Period Data and Sample Collection}

Feeding behavior data were collected as described above for $72 \mathrm{~h}$, starting at feeding on the first day of each infusion period. Blood and rumen fluid samples were collected before the start of each infusion period, after 30 and $54 \mathrm{~h}$ (end of d 1 and 2) of infusion, and immediately after each infusion period ended. Additional blood samples were collected every $4 \mathrm{~h}$ on the first and third day of each infusion period $(1200,1600,2000$, 2400, 0400, and $0800 \mathrm{~h}$ ). Liver biopsies were collected at $1200 \mathrm{~h}$ after 1 and $3 \mathrm{~d}$ of infusion during each period. The samples were processed and stored as described above.

\section{Analysis of Samples}

Feed, orts, and fecal samples were dried in a $55^{\circ} \mathrm{C}$ forced-air oven for $72 \mathrm{~h}$ and analyzed for DM concentration. All samples were ground in a Wiley mill (1-mm screen; Arthur H. Thomas Co., Philadelphia, PA) and analyzed for ash, NDF, indigestible NDF, CP, starch, and ether extract. Ash concentration was determined after $5 \mathrm{~h}$ of oxidation at $500^{\circ} \mathrm{C}$. Concentration of NDF was analyzed according to Mertens (2002). Indigestible NDF was used as an internal marker to estimate total-tract nutrient digestibility (Cochran et al., 1986). Indigestible NDF was estimated as NDF residue after 240-h in vitro fermentation (Goering and Van Soest, 1970); flasks were reinoculated at $120 \mathrm{~h}$ to ensure a viable microbial population. Ruminal fluid for the in vitro incubation was collected from a nonpregnant dry cow fed dry hay only. Crude protein concentration was determined according to Hach et al. (1987). Starch was analyzed using an enzymatic method (Karkalas, 1985) after samples were gelatinized with sodium hydroxide. Glucose was measured using a glucose oxidase method (PGO enzyme product no. P7119; Sigma Chemical Co., St. Louis, MO). Ether extract concentration was determined using a modified Soxhlet apparatus (AOAC, 1990). All nutrients are expressed as percentages of DM determined by drying at $105^{\circ} \mathrm{C}$ in a forced-air oven for more than $8 \mathrm{~h}$.

Plasma samples were analyzed using commercial kits for concentrations of NEFA (NEFA HR kit; Wako Chemicals USA, Richmond, VA), BHBA (kit \#2240; Stanbio Laboratory, Boerne, TX), insulin (Coat-ACount, Siemens Healthcare Diagnostics, Deerfield, IL), and glucagon (kit \#GL-32K; Millipore Corp., Billerica, MA). Plasma glucose concentration was determined using a glucose oxidase method (PGO enzyme product no. P7119, Sigma Chemical Co.). Plasma and rumen fluid VFA concentrations were determined by HPLC according to Oba and Allen (2003a). Rumen ammonia$\mathrm{N}$ concentration was determined by colorimetric assay using the method of Broderick and Kang (1980). Liver acetyl-CoA was analyzed by HPLC using a method previously described (Stocks and Allen, 2012).

\section{RNA Extraction and Real-Time Quantitative PCR}

Expression of genes related to glucose, lipid, and propionate metabolism were analyzed to evaluate responses to treatment infusion of propionic or acetic acid. Methods, primers, and results are reported in the Supplemental Materials (available online at http:// www.journalofdairyscience.org/).

\section{Statistical Analysis}

Feeding behavior, intake, metabolite and hormone responses, and rumen fermentation characteristics data were analyzed using PROC MIXED in SAS (version 9.2; SAS Institute Inc., Cary, NC) with the following model:

$$
\begin{gathered}
\mathrm{Y}_{\mathrm{ijk} k \mathrm{~m}}=\mu+\mathrm{B}_{\mathrm{i}}+\mathrm{C}\left(\mathrm{B}_{\mathrm{i}}\right)_{\mathrm{j}}+\mathrm{P}\left(\mathrm{B}_{\mathrm{i}}\right)_{\mathrm{k}}+\mathrm{D}_{\mathrm{l}}+\mathrm{T}_{\mathrm{m}} \\
+\mathrm{P}_{\mathrm{k}} \mathrm{T}_{\mathrm{m}}+\mathrm{D}_{\mathrm{l}} \mathrm{T}_{\mathrm{m}}+\mathrm{Cov}+\mathrm{T}_{\mathrm{m}} \mathrm{Cov}+\mathrm{e}_{\mathrm{ijklm}},
\end{gathered}
$$

where $Y_{\mathrm{ijklm}}=$ the dependent response variable of interest, $\mu=$ overall mean, $B_{i}=$ fixed effect of block ( $\mathrm{i}=$ 
Table 2. Effects of intraruminal infusion of propionic acid relative to acetic acid on feeding behavior and intake for cows in early lactation (overall effects of treatment)

\begin{tabular}{lcccccc}
\hline & & & & \multicolumn{3}{c}{$P$-value $^{1}$} \\
\cline { 5 - 7 } Item & $\begin{array}{c}\text { Acetic } \\
\text { acid }\end{array}$ & $\begin{array}{c}\text { Propionic } \\
\text { acid }\end{array}$ & $\mathrm{SE}$ & Trt & Per & Trt $\times$ Per \\
\hline DMI, kg/d & 17.0 & 15.9 & 0.70 & 0.05 & 0.06 & 0.07 \\
Meal size, kg & 1.55 & 1.47 & 0.144 & 0.49 & 0.59 & 0.02 \\
Meal frequency, no./d & 11.3 & 11.4 & 0.68 & 0.86 & 0.53 & 0.70 \\
Intermeal interval, min & 83.7 & 89.0 & 7.06 & 0.37 & 0.76 & 0.42 \\
\hline
\end{tabular}

${ }^{1}$ Trt $=$ treatment; Per $=$ period

1 to 3$), \mathrm{C}\left(\mathrm{B}_{\mathrm{i}}\right)_{\mathrm{j}}=$ random effect of cow within block $(\mathrm{j}$ $=4), \mathrm{P}\left(\mathrm{B}_{\mathrm{i}}\right)_{\mathrm{k}}=$ fixed effect of period within block $(\mathrm{k}$ $=1$ to 2$), D_{1}=$ fixed effect of day of the treatment infusion $(1=1$ to 3$), \mathrm{T}_{\mathrm{m}}=$ fixed effect of treatment $(\mathrm{m}=1$ to 2$), \mathrm{P}_{\mathrm{k}} \mathrm{T}_{\mathrm{m}}=$ period $\times$ treatment, $\mathrm{D}_{\mathrm{l}} \mathrm{T}_{\mathrm{m}}=$ day $\times$ treatment, $\mathrm{Cov}=$ effect of covariate, $\mathrm{T}_{\mathrm{m}} \mathrm{Cov}=$ treatment $\times$ covariate, and $\mathrm{e}_{\mathrm{ijklm}}=$ residual, normally distributed. Residuals were determined to be normally distributed by the Shapiro-Wilk test. Treatment effects were declared significant at $P \leq 0.05$ and tendencies for treatment effects at $P \leq 0.10$. Interactions were declared significant at $P \leq 0.10$. Covariate interactions were removed from the model if $P>0.20$. All data are expressed as least squared means and standard error of the means, unless otherwise specified.

\section{RESULTS}

\section{Feed Intake and Feeding Behavior}

Propionic acid infusion, relative to acetic acid infusion, decreased DMI $(P=0.05$; Table 2), despite a treatment-by-period interaction $(P=0.07$; Table 2$)$. During period 1 (Table 3), propionic acid infusion decreased DMI by $18.3 \%$ relative to acetic acid infusion $(14.3$ vs. $17.5 \mathrm{~kg} / \mathrm{d} ; P=0.006)$ but did not affect DMI $(P=0.52)$ during period 2. Although, propionic acid infusion did not affect meal size, meal frequency, or intermeal interval, there was a treatment-by-period interaction for meal size $(P=0.02$; Table 2$)$. The decrease in DMI in period 1 was because propionic acid infusion decreased meal size by $20.7 \%$ (1.30 vs. 1.65 $\mathrm{kg} ; P=0.05$; Table 3 ), whereas meal size in period 2 was not affected by treatment $(P=0.26$; Table 3$)$. The treatment-by-period interaction might have been from a carryover effect of treatment; therefore, the remainder of the results will pertain to the treatment responses from period 1 only. Propionic acid decreased feed intake during the first $4 \mathrm{~h}$ after feeding $(P=0.006$; Table 4) but not during the remaining $20 \mathrm{~h}$ of the day $(P=0.22$; Table 4$)$ and propionic acid decreased water intake $25.3 \%$ relative to acetic acid $(P=0.01$; Table 4$)$.

\section{Interaction Between Treatment and Day of Infusion}

No interaction was observed between infusion treatment and day of the infusion for DMI, total ME intake, meal size, intermeal interval, DMI from 0 to $4 \mathrm{~h}$ and 4 to $24 \mathrm{~h}$, or water intake $(P>0.24$; Table 4$)$. However, a treatment-by-day interaction was observed for meal frequency $(P=0.10)$; propionic acid increased meal frequency on $\mathrm{d} 2$ and 3 relative to $\mathrm{d} 1$ (Figure 1), whereas acetic acid did not.

No significant treatment-by-day interactions were detected for plasma and liver metabolites and hormones during the infusion period (data not shown). However, a significant interaction existed between the covariate day (d 0) and the infusion period for plasma BHBA concentration $(P=0.001$; Figure 2$)$. Propionic acid reduced plasma BHBA concentration from the covariate day to $\mathrm{d} 1$ and the reduction in plasma BHBA concentration was sustained throughout the infusion

Table 3. Effects of intraruminal infusion of propionic acid relative to acetic acid on feeding behavior and intake for cows in early lactation during period 1 (d 3-5) and period 2 (d 10-12)

\begin{tabular}{lcccc}
\hline & Acetic & & & P-value \\
\cline { 4 - 5 } Item & acid & $\begin{array}{c}\text { Propionic } \\
\text { acid }\end{array}$ & SE & Treatment \\
\hline DMI, kg/d & 17.5 & 14.3 & 0.70 & \\
$\quad$ Period 1 & 16.6 & 17.4 & 1.11 & 0.006 \\
Period 2 & 1.65 & 1.30 & 0.12 & 0.05 \\
Meal size, kg & 1.46 & 1.64 & 0.19 & 0.26 \\
Period 1 & & & & \\
Period 2 & & &
\end{tabular}


period, whereas the opposite relationship was observed for acetic acid. Additionally, no effects of propionic acid were observed on plasma glucose, insulin, glucagon, NEFA, acetic acid, or propionic acid concentrations $(P>0.11$; Table 5). Propionic acid decreased plasma BHBA concentration by $72.9 \%$ (5.1 vs. $18.8 \mathrm{mg} / \mathrm{dL} ; P$ $=0.007$; Table 5) and decreased hepatic acetyl-CoA concentration by $62.4 \%(2.85$ vs. $7.58 \mathrm{nmol} / \mathrm{g} ; P=$ 0.04; Table 5) compared with acetic acid.

\section{Interaction Between Treatment and Hepatic Acetyl-CoA on Intake and Feeding Behavior}

Infusion treatment interacted with covariate hepatic acetyl-CoA concentration $(P=0.07$; Table 6$)$; propionic acid had a more pronounced hypophagic effect with greater hepatic acetyl-CoA concentration (Figure 3). The significance of the interaction was greater for DMI during the first $4 \mathrm{~h}$ after feeding $(P=0.007$; Table 6$)$. No interactions were observed between treatment and hepatic covariate acetyl-CoA concentration for other intake or feeding behavior responses (Table 6).

\section{Ruminal $\mathrm{pH}$, VFA Concentration and Profile, and Ammonia-N}

No treatment effects existed on any ruminal parameter measured. The mean rumen $\mathrm{pH}$ was 6.59 and the mean rumen ammonia- $\mathrm{N}$ concentration was $8.22 \mathrm{mM}$. The total rumen VFA concentration averaged 115.4 $\mathrm{m} M$, and the mean acetate and propionate concentrations were 75.6 and $22.5 \mathrm{mM}$, respectively.

\section{DISCUSSION}

Intraruminal propionic acid infusion decreased DMI relative to acetic acid as previously reported in the literature and reviewed by Allen et al. (2009). How-

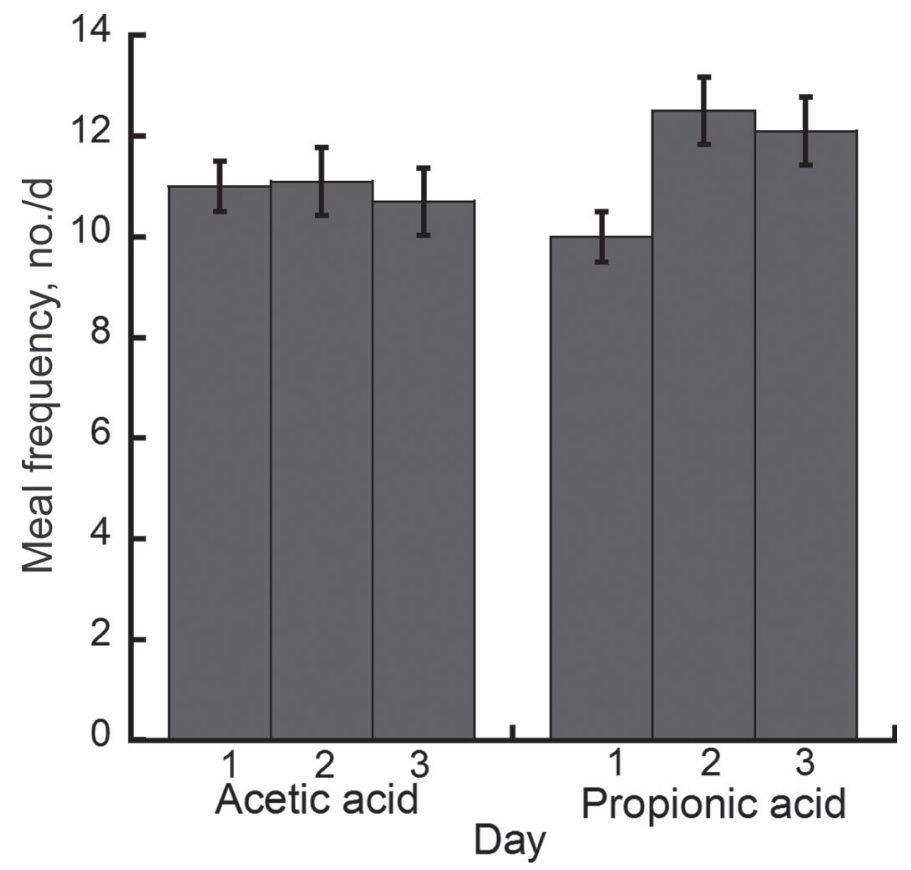

Figure 1. The interaction $(P=0.10)$ between treatment infusion and meal frequency in infusion period 1 (d 3-5) for cows infused intraruminally with either propionic or acetic acid.

ever, the significant treatment-by-period interaction suggested a potential carryover effect of the propionic acid treatment and led us to analyze each period independently. The $18.3 \%$ reduction in DMI by propionic acid infusion during period 1 of this experiment was expected and consistent with previous results for cows at a similar stage of lactation (Oba and Allen, 2003b; Stocks and Allen, 2012). The ruminant liver rapidly extracts absorbed propionic acid (Benson et al., 2002) and up to $70 \%$ of propionic acid in the portal vein is extracted on the first pass (Reynolds et al., 2003). In contrast, acetic acid is not readily extracted from the blood by the liver (Reynolds, 1995) because the activ-

Table 4. Effect of intraruminal infusion of propionic acid relative to acetic acid on feeding behavior for cows in early lactation during period 1 (d 3-5) only

\begin{tabular}{|c|c|c|c|c|c|c|}
\hline \multirow[b]{2}{*}{ Item } & \multirow[b]{2}{*}{$\begin{array}{l}\text { Acetic } \\
\text { acid }\end{array}$} & \multirow[b]{2}{*}{$\begin{array}{l}\text { Propionic } \\
\text { acid }\end{array}$} & \multirow[b]{2}{*}{$\mathrm{SE}$} & \multicolumn{3}{|c|}{$P$-value } \\
\hline & & & & $\operatorname{Trt}^{1}$ & Day & Trt $\times$ day \\
\hline DMI, $\mathrm{kg} / \mathrm{d}$ & 17.5 & 14.3 & 0.70 & 0.006 & 0.53 & 0.47 \\
\hline ME intake, MJ/d & 111 & 92 & 6.41 & 0.03 & 0.15 & 0.56 \\
\hline Total ME intake, MJ/d & 121 & 110 & 6.41 & 0.15 & 0.15 & 0.56 \\
\hline Meal size, $\mathrm{kg}$ & 1.65 & 1.30 & 0.12 & 0.05 & 0.18 & 0.24 \\
\hline Meal length, min & 32.3 & 28.5 & 1.84 & 0.17 & 0.46 & 0.15 \\
\hline Meal frequency, no. & 10.9 & 11.5 & 0.67 & 0.54 & 0.13 & 0.10 \\
\hline Intermeal interval, min & 87.3 & 83.9 & 6.85 & 0.72 & 0.95 & 0.46 \\
\hline DMI $(0-4 \mathrm{~h}), \mathrm{kg}$ & 8.23 & 5.86 & 0.75 & 0.006 & 0.04 & 0.30 \\
\hline DMI (4-20 h), kg & 9.25 & 8.41 & 0.73 & 0.22 & 0.64 & 0.41 \\
\hline Water intake, L & 67.5 & 50.4 & 3.81 & 0.01 & 0.26 & 0.24 \\
\hline
\end{tabular}

${ }^{1}$ Trt $=$ treatment. 
Table 5. Effect of intraruminal infusion of propionic acid relative to acetic acid on plasma metabolite and hormone concentrations and hepatic acetyl-CoA during period 1 (d 3-5)

\begin{tabular}{lcccc}
\hline & Acetic & & & $P$-value \\
\cline { 4 - 5 } Item & acid & $\begin{array}{c}\text { Propionic } \\
\text { acid }\end{array}$ & SE & Treatment \\
\hline Glucose, $\mathrm{mg} / \mathrm{dL}$ & 48.1 & 50.8 & 2.16 & 0.19 \\
Insulin, $\mu \mathrm{IU} / \mathrm{mL}$ & 2.36 & 3.99 & 1.39 & 0.18 \\
Glucagon, $\mathrm{pg} / \mathrm{mL}$ & 176 & 168 & 40.1 & 0.73 \\
NEFA, $\mu \mathrm{Eq} / \mathrm{L}$ & 910 & 747 & 181.6 & 0.42 \\
BHBA, $\mathrm{mg} / \mathrm{dL}$ & 18.8 & 5.1 & 2.82 & 0.007 \\
Acetic acid, $\mathrm{m} M$ & 1.06 & 0.69 & 0.15 & 0.11 \\
Propionic acid, $\mathrm{m} M$ & 0.38 & 0.38 & 0.04 & 0.87 \\
Hepatic acetyl-CoA, nmol/g & 7.58 & 2.85 & 1.92 & 0.04 \\
\hline
\end{tabular}

ity of acetyl-CoA synthetase is low (Ricks and Cook, 1981). As a result, propionic acid can stimulate oxidation of hepatic acetyl-CoA (Allen et al., 2009), which may stimulate satiety, whereas acetic acid does not. Propionic acid infusion decreased water intake relative to acetic acid infusion, consistent with previous work in our laboratory (Stocks and Allen, 2012). Water intake is positively correlated to DMI (Woodford et al., 1984), and most variation in water intake is related to variation in DMI (Murphy et al., 1983). Therefore, the decrease in water intake by propionic acid (Table 4) is likely explained by the decrease in DMI, which is consistent with the treatment responses and with previous results (Stocks and Allen, 2012).

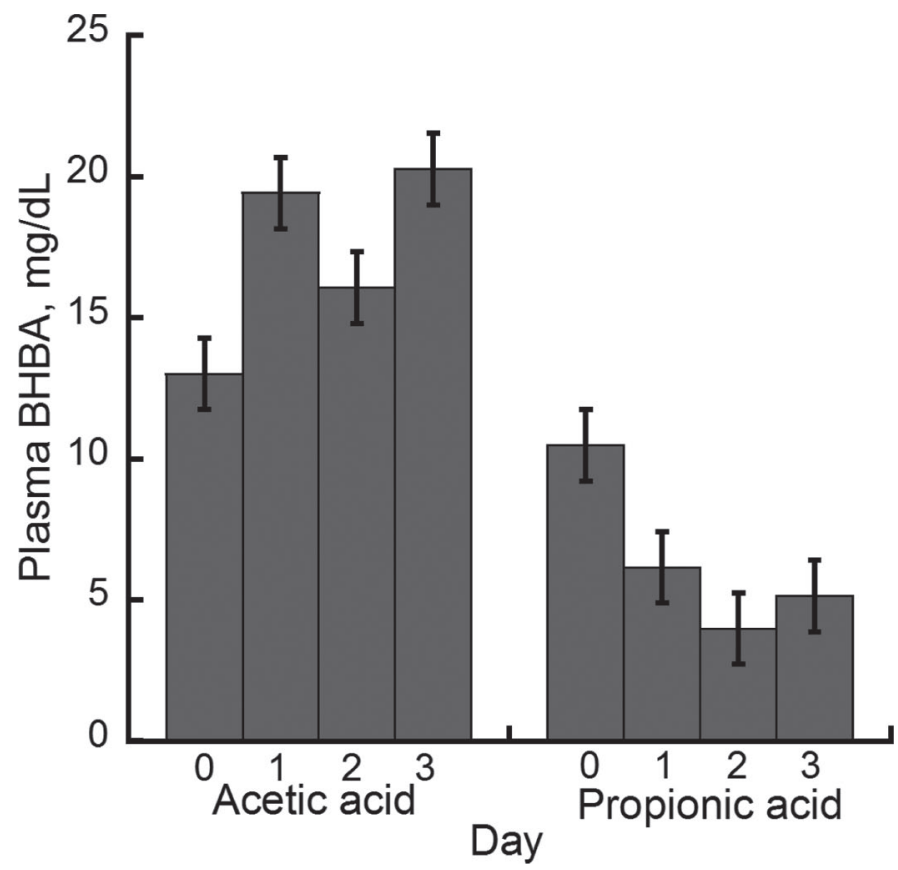

Figure 2. Interaction $(P=0.001)$ between treatment and day for plasma BHBA concentration from the covariate day to infusion period 1 (d 3-5) for cows infused intraruminally with either propionic or acetic acid
The current experiment and previous experiments in our laboratory (Oba and Allen, 2003b; Stocks and Allen, 2012) have shown that propionic acid is hypophagic for cows in early lactation, particularly when cows are in a lipolytic state. Short-term infusions of propionic acid have caused hypophagia when cows are in a lipolytic state (Oba and Allen, 2003b; Stocks and Allen, 2012), but it is necessary to explore the longer-term effect of propionic acid infusion on feed intake to determine if cows adapt to the increased propionic acid load. This experiment was designed to evaluate the adaptive response to propionic acid infusion over the 3 -d infusion period. We anticipated that propionic acid would decrease DMI on the first day of the infusion period but that the depression would be alleviated as the infusion progressed and hepatic acetyl-CoA concentration decreased. The lack of a significant treatment-by-day interaction for DMI (Table 4) does not support our hypothesis, and propionic acid infusion resulted in a sustained decrease in DMI over the course of the 3-d infusion period. However, propionic acid infusion, relative to acetic acid infusion, decreased, but did not deplete, plasma BHBA (Figure 2) and hepatic acetyl-CoA concentrations (data not shown). Although no treatment-by-day interaction for plasma BHBA concentration was observed for the 3 -d infusion period (data not shown), we did observe an interaction between treatment and day for the covariate day ( $\mathrm{d} 0$ ) and the 3 infusion days for plasma BHBA concentration. The $41.4 \%$ reduction in plasma BHBA concentration from the covariate day to $d 1$ of the infusion period (after $24 \mathrm{~h}$ of treatment infusion) is consistent with previous results (Oba and Allen, 2003b; Stocks and Allen, 2012), and this reduction was sustained for the duration of the infusion period (Figure 2). The decrease in plasma BHBA concentration could have been a result of (1) decreased $\beta$-oxidation of NEFA, (2) decreased ketogenesis, or (3) increased oxidation of acetyl-CoA (Stocks and Allen, 2012). The decrease in plasma BHBA and hepatic acetyl-CoA concentrations are likely a result of propionic acid stimulating increased oxidation of acetyl-CoA in the tricarboxylic acid cycle 


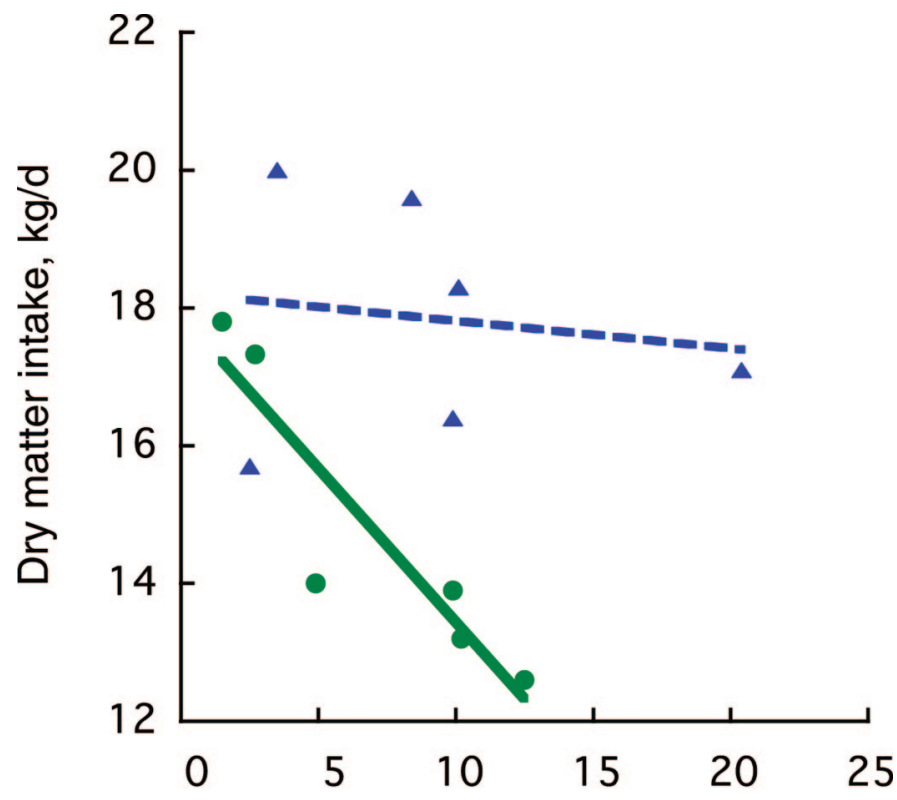

Liver Acetyl CoA, nmol/g of wet weight

Figure 3. Interaction $(P=0.07)$ between treatment and liver acetyl-CoA concentration for DMI during the 3 -d infusion in period 1 (d $3-5$ ) for cows infused intraruminally with propionic acid (solid line) or acetic acid (dotted line). Color version available in the online PDF.

(reviewed by Allen et al., 2009) and decreasing ketogenesis (Faulkner and Pollock, 1986) by decreasing the activity of 3-hydroxy-3methyl-glutaryl (HMG)-CoA synthase (Lowe and Tubbs, 1985). This would be consistent with the reduced meal size, resulting in a decrease in DMI, as observed.

Propionic acid infusion decreased meal size but not meal frequency, resulting in a decrease in DMI (Table 4 ), consistent with our previous results (Oba and Allen, 2003b; Stocks and Allen, 2012). We also observed that the hypophagic effect of propionic acid was within the first $4 \mathrm{~h}$ following feeding (Table 4 ), which could be a result of the larger meal size during this time (data not shown). The first 2 meals, which generally occur within the first $4 \mathrm{~h}$ of feeding, tend to be the largest meals observed for cows throughout the day (Dado and Allen, 1994), and subsequent meals are smaller. The production of propionic acid in the rumen, and subsequent flux to the liver would be largest within the time course of the larger meals. Additionally, plasma NEFA concentration, and likely hepatic acetyl-CoA concentration, is highest at feeding and reaches a nadir by $4 \mathrm{~h}$ postfeeding (Allen et al., 2005). Increased flux of propionic acid to the liver would stimulate oxidation of hepatic acetyl-CoA, increasing energy charge within the meal, leading to a decrease in meal size and DMI during the first $4 \mathrm{~h}$ following feeding, as observed. However, because plasma NEFA concentration is decreased within $4 \mathrm{~h}$ of feeding and remains low through most of the day and only begins to increase within hours of the next conditioned meal at feeding, it is likely that propionic acid would have less effect on DMI from 4 to $20 \mathrm{~h}$ postfeeding compared with the first $4 \mathrm{~h}$ postfeeding, consistent with our results.

The interaction between treatment and hepatic acetyl CoA concentration for DMI (Figure 3) was consistent with previous research in our laboratory (Stocks and Allen, 2012). Propionic acid was more hypophagic when hepatic acetyl-CoA concentration was high when cows were in a lipolytic state (e.g., early lactation). Hypophagia from propionic acid was sustained over the 3 -d infusion period despite the continued reduction, but not depletion, of hepatic acetyl-CoA concentration. We cannot discern whether hypophagia from propionic acid occurs simply in the presence of hepatic acetyl-CoA or rather if it is due to the rate of reduction of the pool of hepatic acetyl-CoA.

Additionally, liver samples were collected only once per day during this experiment, so we were unable to determine the temporal pattern of accretion or deple-

Table 6. Effect of intraruminal infusion of propionic acid relative to acetic acid on feeding behavior for cows in early lactation during period 1 (d $3-5)$

\begin{tabular}{|c|c|c|c|c|c|c|}
\hline \multirow[b]{2}{*}{ Item } & \multirow[b]{2}{*}{$\begin{array}{l}\text { Acetic } \\
\text { acid }\end{array}$} & \multirow[b]{2}{*}{$\begin{array}{l}\text { Propionic } \\
\text { acid }\end{array}$} & \multirow[b]{2}{*}{$\mathrm{SE}$} & \multicolumn{3}{|c|}{$P$-value ${ }^{1}$} \\
\hline & & & & Trt & $\begin{array}{c}\mathrm{Cov} \\
\mathrm{AcCoA}\end{array}$ & $\begin{array}{c}\text { Trt } \times \text { Cov } \\
\mathrm{AcCoA}\end{array}$ \\
\hline DMI, $\mathrm{kg} / \mathrm{d}$ & 17.5 & 13.9 & 0.58 & 0.72 & 0.30 & 0.07 \\
\hline ME intake, MJ/d & 111 & 88 & 5.8 & 0.83 & 0.33 & 0.16 \\
\hline Total ME intake, MJ/d & 121 & 106 & 5.8 & 0.72 & 0.33 & 0.16 \\
\hline Meal size, $\mathrm{kg}$ & 1.65 & 1.30 & 0.12 & 0.05 & 0.40 & 0.32 \\
\hline Meal length, min & 32.4 & 28.8 & 1.85 & 0.20 & 0.88 & 0.98 \\
\hline Meal frequency, no. & 10.9 & 11.4 & 0.68 & 0.61 & 0.79 & 0.96 \\
\hline Intermeal interval, min & 87.3 & 83.9 & 6.85 & 0.72 & 0.27 & 0.55 \\
\hline DMI (0-4 h), kg & 8.24 & 5.37 & 0.45 & 0.82 & 0.08 & 0.007 \\
\hline DMI (4-20 h), kg & 9.25 & 8.41 & 0.73 & 0.22 & 0.59 & 0.83 \\
\hline Water intake, L & 67.5 & 50.4 & 3.90 & 0.01 & 0.25 & 0.26 \\
\hline
\end{tabular}

${ }^{1}$ Trt $=$ treatment; Cov AcCoA = covariate acetyl-CoA. 
tion of hepatic acetyl-CoA throughout the course of a day and how this may have affected feed intake and feeding behavior. The largest meals generally occurred within the first $4 \mathrm{~h}$ following feeding and the greatest hypophagic effects of propionic acid infusion occurred during this same time period, so it is possible that either the pool of acetyl-CoA was largest during this time or the rate of oxidation of acetyl-CoA was highest during this time, stimulating satiety. We speculate that acetyl-CoA accumulated in the liver in the hours before feeding, reaching its peak right at the beginning of the conditioned meal at feeding, and then was subsequently oxidized during large meals immediately following feeding. The idea of a cyclic pattern of accumulation and depletion of acetyl-CoA in the ruminant liver is consistent with the decrease in feed intake observed during the first $4 \mathrm{~h}$ following feeding in the current study, with no difference in intake during the remaining $20 \mathrm{~h}$ of the day. Although data on diurnal variation of hepatic acetyl-CoA concentration are not available, the variation is likely consistent with the diurnal variation in plasma NEFA concentration, which is highest immediately before feeding (Allen et al., 2005).

\section{CONCLUSIONS}

Feed intake in the periparturient period is likely suppressed by oxidation of NEFA mobilized from adipose tissue. Diet composition likely interacts with the lipolytic state because of differences in the supply of propionate to the liver within the timeframe of meals. Propionate supply to the liver likely stimulated oxidation of acetyl-CoA, resulting in increased energy charge, which stimulated satiety. Greater flux of propionate to the liver within the timeframe of meals with higher starch fermentability likely decreases meal size and DMI. Although attenuation of propionic acid-stimulated hypophagia may happen over the longer-term as the hepatic acetyl-CoA pool is depleted, our data do not support adaptation to elevated propionic acid load over $3 \mathrm{~d}$. More research is needed to determine the diurnal variation in hepatic acetyl-CoA, as this could lend additional information as to the within-day control of feed intake. Feeding studies evaluating cow response to highly fermentable diets and longer-term infusion studies would also generate valuable information for use in determining how to feed and manage cows during the early postpartum period.

\section{ACKNOWLEDGMENTS}

We gratefully acknowledge B. J. Bradford (Kansas State University, Manahttan) for contributions related to the initial planning of this experiment and D. G.
Main and R. A. Longuski (both of Michigan State University, East Lansing) for technical assistance.

\section{REFERENCES}

Allen, M. S., B. J. Bradford, and K. J. Harvatine. 2005. The cow as a model to study food intake regulation. Annu. Rev. Nutr. 25:523-547.

Allen, M. S., B. J. Bradford, and M. Oba. 2009. Board-Invited Review: The hepatic oxidation theory of the control of feed intake and its application to ruminants. J. Anim. Sci. 87:3317-3334.

AOAC (Association of Official Analytical Chemists). 1990. Official Methods of Analysis. 15th ed. AOAC, Gaithersburg, MD.

Bell, A. W. 1995. Regulation of organic nutrient metabolism during the transition from late pregnancy to early lactation. J. Anim. Sci. 73:2804-2819.

Benson, J. A., C. K. Reynolds, P. C. Aikman, B. Lupoli, and D. E. Beever. 2002. Effects of abomasal vegetable oil infusion on splanchnic nutrient metabolism in lactating dairy cows. J. Dairy Sci. 85:1804-1814

Bradford, B. J., and M. S. Allen. 2005. Phlorizin administration increases hepatic gluconeogenic enzyme mRNA abundance but not feed intake in late-lactation dairy cows. J. Nutr. 135:2206-2211.

Bradford, B. J., A. D. Gour, A. S. Nash, and M. S. Allen. 2006. Propionic acid challenge test have limited value for investigating bovine metabolism. J. Nutr. 136:1915-1920.

Broderick, G. A., and J. H. Kang. 1980. Automated simultaneous determination of ammonia and total amino acids in rumen fluid and in vitro media. J. Dairy Sci. 63:64-75.

Cochran, R. C., D. C. Adams, J. D. Wallace, and M. L. Galyean. 1986. Predicting the digestibility of different diets with internal markers: Evaluation of four potential markers. J. Anim. Sci. 63:1476-1483.

Dado, R. G., and M. S. Allen. 1993. Continuous computer acquisition of feed and water intakes, chewing, reticular motility, and ruminal pH of cattle. J. Dairy Sci. 76:1589-1600.

Dado, R. G., and M. S. Allen. 1994. Variation in and relationships among feeding, chewing, and drinking variables for lactating dairy cows. J. Dairy Sci. 77:132-144.

Dann, H. M., G. A. Varga, and D. E. Putnam. 1999. Improving energy supply to late gestation and early postpartum dairy cows. J. Dairy Sci. 82:1765-1778.

Faulkner, A., and H. T. Pollock. 1986. Propionic acid metabolism and its regulation by fatty acids in ovine hepatocytes. Comp. Biochem. Physiol. B 84:559-563.

Goering, H. K., and P. J. Van Soest. 1970. Forage Fiber Analysis (Apparatus, Reagents, Procedures, and Some Applications). Agricultural Handbook No. 379. US Department of Agriculture-Agricultural Research Service (USDA-ARS), Washington, DC.

Gulay, M. S., M. J. Hayen, M. Liboni, T. I. Belloso, C. J. Wilcox, and H. H. Head. 2004. Low doses of bovine somatotropin during the transition period and early lactation improves milk yield, efficiency of production, and other physiological responses of Holstein cows. J. Dairy Sci. 87:948-960.

Hach, C. C., B. K. Bowden, A. B. Kopelove, and S. V. Brayton. 1987. More powerful peroxide Kjeldahl digestion method. J. Assoc. Off. Anal. Chem. 70:783-787.

Huntington, G. B. 1997. Starch utilization by ruminants: From basics to the bunk. J. Anim. Sci. 75:852-867.

Ingvartsen, K. L., and J. B. Andersen. 2000. Integration of metabolism and intake regulation: A review focusing on periparturient animals. J. Dairy Sci. 83:1573-1597.

Karkalas, J. 1985. An improved enzymic method for the determination of native and modified starch. J. Sci. Food Agric. 36:1019-1027.

Lowe, D. M., and P. K. Tubbs. 1985. Succinylation and inactivation of 3-hydroxyl-3-methylglutaryl-CoA synthase by succinyl-CoA and its possible relevance to the control of ketogenesis. Biochem. J. 232:37-42.

Mertens, D. R. 2002. Gravimetric determination of amylase-treated neutral detergent fiber in feeds using refluxing in beakers or crucibles: Collaborative study. J. AOAC Int. 85:1217-1240. 
Murphy, M. R., C. L. Davis, and G. C. McCoy. 1983. Factors affecting water consumption by Holstein cows in early lactation. J. Dairy Sci. $66: 35-38$.

NRC. 2001. Nutrient Requirements of Dairy Cattle. 7th rev. ed. National Academy of Sciences, Washington, DC.

Oba, M., and M. S. Allen. 2003a. Effects of corn grain conservation method on feeding behavior and productivity of lactating cows at two dietary starch concentrations. J. Dairy Sci. 86:174-183.

Oba, M., and M. S. Allen. 2003b. Dose-response effects of intraruminal infusion of propionic acid on feeding behavior of lactating cows in early or midlactation. J. Dairy Sci. 86:2922-2931.

Reynolds, C. K. 1995. Quantitative aspects of liver metabolism in ruminants. Pages 351-372 in Ruminant Physiology: Digestion, Metabolism, Growth and Reproduction. W. von Engelhardt, S. Leonhard-Marek, G. Breves, and D. Giesecke, ed. Ferdinand Enke Verlag, Stuttgart, Germany.

Reynolds, C. K., P. C. Aikman, B. Lupoli, D. J. Humphries, and D. E. Beever. 2003. Splanchnic metabolism of dairy cows during the transition from late gestation through early lactation. J. Dairy Sci. 86:1201-1217.

Ricks, C. A., and R. M. Cook. 1981. Regulation of fatty acid uptake by mitochondrial acyl CoA synthetases of bovine liver. J. Dairy Sci. 64:2324-2335.

Stocks, S. E., and M. S. Allen. 2012. Hypophagic effects of propionic acid increase with elevated hepatic acetyl coenzyme A concentration for cows in the early postpartum period. J. Dairy Sci. 95:3259-3268.

Wildman, E. E., G. M. Jones, P. E. Wagner, R. L. Boman, H. F. Troutt Jr., and T. N. Lesch. 1982. A dairy cow body condition scoring system and its relationship to selected production characteristics. J. Dairy Sci. 65:495-501.

Woodford, S. T., M. R. Murphy, and C. L. Davis. 1984. Water dynamics of dairy cattle as affected by initiation of lactation and feed intake. J. Dairy Sci. 67:2336-2343. 